\title{
〔W.P.S.J. の紹介〕
}

\section{W.P.S.J., Vol. 50, No. 1（1994）〔目次紹介〕}

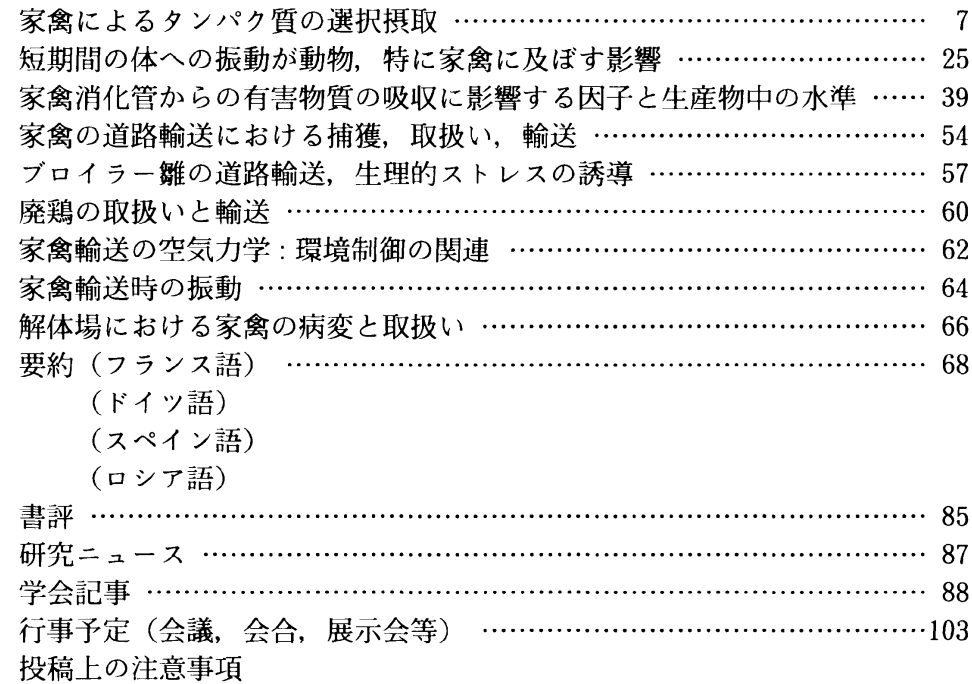

\section{家禽によるタンパク質の選択摂取}

J.M. Forbes \& F. ShariatMAdARI : W.P.S.J., 50, (1), 7 (1994)

はじめに

20 世紀のはじめより，家禽の自由選択摂取が注目さ れ，1930 年代には鳥類が複数のバランスのとれていない 飼料からバランスをとって飼料を選択攝取することが観 察された。

単一の飼料を給与する場合, 飼料中のエネルギー含量 により摂取量は決定されるが，2 種類の飼料を給与する 場合, 鶏は 2 つの栄養素を個別に調節することができ る。タンパク質源となる飼料原料は高価なため, 飼料中 のタンパク質含量を最適にすることに大きな関心がもた れている。このため，選択摄取の栄養素としてタンパク 質が注目されている。

そこで，本総説では選択摂取に関するこれまでの報告 を, 家离によるタンパク質の選択摂取の原理, 機構, 夕 ンパク質要求量に従った選択摄取の能力, 要求量の变化 に対応した選択摄取および選択摄取によるアミノ酸摂取 量の制御についてとりまとめた。

\section{選択摄取の原理}

選択摄取の原理を考える場合，調節される成分が 2 種 類では直線, 3 種類では三角形, 4 種類では四面体により 説明することができる。たとえば，エネルギー，タンパ
ク質およびミネラルの 3 種類の成分が調節される場合, 三角形の底辺とその底辺に対する頂点が各成分の $0 \%$ と $100 \%$ であり，飼料は三角形の中に位置することとなる。 各成分に過不足ない飼料は三角形の中心部分に位置し, このような飼料は単一で動物の要求量を満たすと考えら れる。中心部分から外れた飼料は単一では要求量を満た すことはできないため, 複数の飼料給与で選択摂取させ る必要がある。しかし，外れた 2 種類の飼料が位置する 点を結ぶ直線が中心部分に接していない場合，選択摄取 させても要求量を満たすことはない。したがって，選択 摂取に関する試験を行う場合，少なくとも 1 種類は中心 部分から外れた飼料を用いる必要がある。また，単一の 飼料給与により動物の要求量を満たすには, 中心部分に 位置する飼料を給与することが必要である。

動物が栄養素の要求量を満たすために 2 種類の飼料を 選択摄取する場合，その栄養素に対して特定の食欲を示 すことが必要である。これまでの研究において，食欲を 示す栄養素として各種のミネラルやビタミンが検討され てきた。

鷄が栄養的にバランスをとって選択摂取するには，各 飼料の特徴を識別し，その飼料の特性と摄取することに より生ずる代謝の感覚の違いを関連づける必要がある。 飼料に外観や白いなどの特徵がない場合, 鶏は選択摄取 できない。とくに，色は飼料の選択攝取を決定する上で 大きな特徴と考えられている。また，鳥類は十分な味覚 
（味・風味を識別する能力）を有しているが，すぐに順応 して飼料の味・風味による選択摄取を行わなくなるこよ が示されている。一般に鶏では飼料の味: 風味よりも外 観などの特徴が選択摄取に大きく影響するあのと考えら れている。

\section{選択揳取の機構}

鵎が異なる飼料の特徵を識別して選択摂取する過程で は，多くの代謝反応が関連するものと推察される。ラッ 卜などの実験動物において自己選択摄取と神経伝達物質 の濃度や代謝回転の変化の関係が報告されてきた。炭水 化物の摄取量は脳中のノルアドレナリンにより促進さ れ，5-ハイドロキシトリプタミンにより抑制される。脂 肪の摂取量はガラニンやアルドステロンにより促進さ れ，ドーパミンにより抑制される。タンパク質の摄取量 はオピオイドや成長ホルモン放出因子により增加する。 また，コルチコトロピン放出因子を脸室へ注入すること により, 炭水化物摂取量を变化させることなくタンパク 質と脂肪の拱取量を抑制できる。しかし，鳥類では飼料 摄取の神経化学的な制御に関する研究は非常に少なく, 飼料の選択摄取における研究は皆無である。

\section{タンパク質含量の異なる 2 種類の飼料からタンパク質 要求量に従って選択摄取する能力}

要求量に比べてタンパク質含量の高い飼料と低い飼料 を選択摂取させたブロイラーでは，成長のために最適な タンパク質摂取量となるように $2 つ の$ 飼料を採食する。 両方の飼料のタンパク質含量が過剩，あるいは不足であ る場合, ブロイラーは要求量に比較的に近い飼料を優先 的に採食する。また， 4 種類の同一エネルギー含量で異 なるタンパク質含量の飼料，あるいは同一タンパク質含 量で 4 種類の異なるエネルギー含量の飼料を用いた選択 摂取の検討により，ブロイラーは最小限の乾物摄取量で 理想的なカロリー・タンパク質比の飼料となるように選 択摄取する。

産卵舀は適当な学習を施された場合，摂取する飼料の タンパク質含量のバランスを取ることができるが，ブロ イラーほどタンパク質摂取量を調節する能力を持たない ことが多くの報告から示されている。しかし，ブロイ ラーとの違いは週柃の差に起因しているとも考えられ る。

最す極端な選択摂取は無タンパク質飼料と高タンパク 質飼料の選択摂取である。グルコース溶液と飼料を給与 することはこの極端な選択摂取の 1 例である。グルコ一 ス溶液を給与することで飲水をさせない場合，グルコー ス溶液は無タンパク質飼料であり水分の給源でもある。 グルコース溶液の供給により, 飼料摂取量は成長中の鶏 では低下し，成鶏では増加する。この成長中の鷄におけ
る飼料拱取量の低下は, 成長中の鷂のタンパク質要求量 が高く, 給与タンパク質が不足したための現象であると 推察された。以上の結果から，さまざまな環境下におい て鳥類は要求量に合った十分なタンパク質を含有する飼 料を摂取することにより無タンパク質飼料の摄取を調節 することが明らかとなった。

エネルギーとタンパク質の要求量の変化に対応したタ ンパク質の選択摂取

ブロイラーは成長するとともに体タンパク質の蓄積速 度は一定となり, エネルギー要求量は增加し続けるため に, 飼料のタンパク質: エネルギーの要求量は低下す る。したがって，ブロイラーは成長とともに低タンパク 質の飼料を選扒掑取するようになる。

成長能力の高い（Lean 部分の蓄積能力の高い）系統 の鷄は成長能力の低い系統の鶏に比べて低タンパク質飼 料よりも高タンパク質飼料を多く選択摄取し，体脂肪を 多く蓄積する選抜系統の鷂は lean 系統の鶏よりも単位. エネルギー当りのタンパク質摂取量が多くなるように選 択摄取する。また，雄は雌よりも多くの高タンパク質飼 料を選択摄取する。

環境温度の增加はエネルギー要求量を低下させるた め, 選択撕取される飼料のタンパク質とエネルギーの比 率を上昇させるものと推定される。しかし，高温環境下 に暴露した鷄は摄取する飼料のタンパク質含量が高くな るようには選択摄取しないことが報告されている。この 推定と結果の相違はタンパク質代謝による高い熱量増加 のために生じたものと考えられる。

\section{アミノ酸摂取量の制御}

選択㠌取によるアミ/酸摂取量の制御に関する研究は 少ないが，アミノ酸の中であリジンとメチオニンに関す る検討が比較的に多く行われてきた。

成長中の七ナは低リジン飼料と高リジン飼料を区別で きるが，選択摄取によりリジンの摄取量は完全には制御 されない。

ブロイラーはメチオニン久乏時に通常の鶏よりもメチ オニン添加飼料を多く選択摄取する。一方，産卵䳕は低 メチオニン飼料に対する選択摄取を施した場合，いくら かのメチオニン強化飼料を採食するが，普通の卵生産を 維持するために充分な量ではない。

\section{結 論}

以上の結果より，家禽はタンパク質に関して“栄養の 知識”を示す, すなわち, 要求量に従って選択摂取する 能力を有していることが明らかとなった。しかし，その “栄養の知識”を示すには, 各飼料の特徴を識別し, 飼料 の特性と摂取することにより生ずる代謝の感覚の違いの 関連づけが必要である。したがって，これまで得られた 
いくつかの不十分な結果の原因は飼料の特性と代謝の感 覚の違いを関連づけるための学習が不足したためと推察 された。

\section{（農水省畜試・村上 斉）}

\section{家禽消化管からの有害物質の吸収に影篅する因子ट 生産物中の水準}

C.A. KAN : W.P.S.J., 50, (1), 39 (1994)

家禽飼料の有機塩素系殺虫剤, 重金属, 放射性同位元 素, マイコトキシンなどの有害物質による污染は，避け られない場合がある。

このレビューでは, 家禽の污染を減少させる可能性 と, 家离産物の污染水準について論じた。ここでは, 通 常飼料や飼料原料中に存在しない有害物質に限定した。 このため, 配糖体のような非栄養性因子については言及 していない。

\section{1. 有機塩素系殺虫剂}

有機塩素系殺虫剤の小腸からの吸収は木炭のような高 吸収性物質との競合で抑えられるであろう。これまでの 研究報告をみると，高水準の DDT が飼料中に存在する 場合は活性化木炭（activated charcoal）の添加は効果 的であるが，低水準の DDT の取り込みや蓄積を減少さ せるには良い方法とはいえないようである。

体内に吸収されたジェルドリンを減少させるには，自 由攝取量の $30 \sim 50 \%$ の厳しい絶食が効果的であるとい う報告があるが，実際に行うには問題がある。

鶏卵からリンデン（六塩化ベンゼン）などの揮発性の ある有機塩素系殺虫剤を除去するには，凍結乾燥が有効 であり,これにより $\mathrm{PCB}$ あ若干減少する。調理による影 響はないようである。紫外線あるいはガンマ線照射に よってミレックスは減少する。

数時間の調理によって，屠体中のリンダン, DDT，エ ンドリン，ジェルドリンの大部分は肉汁中に放出される が，へプタクロルは逆に強く保持される。調理・加熱中 にリンダン, ヘプタクロルエポキサイド, DDT, クロル ダン，テロドリンは減少する。一方，エンドリン，ジェ ルドリン，アルドリン，オベックス，ケルサンは減少し ない。

油で揚げると，有機塩素系殺虫剂，DDT，テプタクロ ルは減少する。一方，DDEやジェルドリンは減少しな い。ローストするとリンダンが減少するが，へキサクロ ルベンゼンは減少しない。加工ソーセージ熟成過程では DDTとリンダンが減少する。

多量のリンダン，エンドリン，アルドリン，ジェルド
リン, ヘプタクロル, DDTを含む家禽肉を蛋白質濃縮物 とすることによって，これらを検出限界以下にすること ができる。この方法は污染肉を扱ううえで最も良い方法 であろう。

\section{2. 重金属}

小腸からの重金属の吸収はその存在形態によって異な る。重金属は硝酸塩, 酢酸塩などの溶解性の高いむのか ら, 硫化物のような溶解性の極めて低いものまである。 また, 脂肪の溶解性も吸収に影響する。

低水準のカドミウムの場合は, その有害作用は鉄, 銅, 亜鉊, セレン, マンガンの添加によって防止できる。亜 鉛欠乏はカドミウム蓄積を促進する。ビタミン C とセレ ンはカドミウムの蓄積を抑制する大きな効果を持ってい る。鉄は中程度の効果を持っている。銅の高水準添加は 逆にカドミウム蓄積を促進する。セレンの添加で組織中 のカドミウムが減少することも認められている。ビタミ ン C は, 鉄, カルシウムあるいは銅とのあいだに交互作 用があり，これらの影響を増幅する。カドミウムの蓄積 は, 十分なカルシウム水準と高い $\mathrm{Ca}: \mathrm{P}$ 比の場合に少な くなる。ビタミン D はこれをさらに少なくする。システ インは発育改善効果はないが, 腎臓のカドミウム蓄積を 滅少させる。

鉛による害作用は高水準のリンとカルシウム, メチオ ニンによって緩和される。バナジゥムの有害作用は, EDTA, アスコルビン酸, クロム, 高蛋白質によって緩 和される。

しかし 家离産物中に含まれる重金属の減少の可能性 について利用できる公表情報はない。理論的には, 適切 なイオン交換処理を行うことによって液状産物から低減 することは可能であろう。

\section{3. 放射性同位元素（セシウム）}

ベントナイト，ゼオライトなどの吸収剂は家禽におけ るセシウム 137 などの放射性同位元素の吸収をある程度 低減させる。5〜10\%の塩水に 7 日間塩漬すると, セシ ウム 137 污染の除去が観察されている。

\section{4. マイコトキシン}

飼料原料中のマイコトキシン生成は防止すべきであ り，これは可能である。飼料原料のアンモニア処理はア フラトキシン水準を低減する良い方法である。 $\mathrm{Na} \cdot \mathrm{Ca}$ アルミノケイ酸のような吸収剤は飼料に起因するアフラ トキシン污染による影響を軽減することが示唆されてい る。また，マイコトキシンを分解する微生物が発見され ており，この活用も污染除去の一方法であろう。

（農水省畜試・武政正明） 